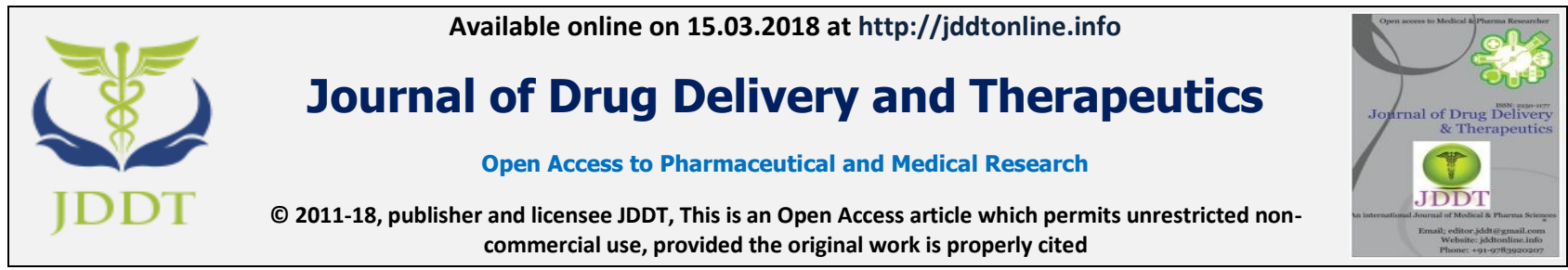

Open $\bigcirc$ Access

Research Article

\title{
ENHANCEMENT OF SOLUBILITY AND DISSOLUTION RATE OF SIMVASTATIN BY USING SOLID DISPERSION TECHNIQUE ALONG WITH DIFFERENT COMBINATION OF POLYMERS
}

\author{
Komal, Taranjit Kaur*, Ajeet Pal Singh, Amar Pal Singh, Prachi Sharma \\ Department of Pharmaceutics, St. Soldier Institute of Pharmacy, Jalandhar, Punjab, India
}

\section{ABSTRACT}

The solubility and dissolution rate of simvastatin, a drug used for the treatment of hyperlipidaemia. Simvastatin is a selective competitive inhibitor of HMG Co A reductase. However its absolute bioavailability is $5 \%$. To increase the solubility of drug solid dispersion was prepared. Solid dispersion preliminary solubility analysis was carried out for the selection of the carrier and solid dispersion was prepared with Hydroxy Propyl Methyl Cellulose (HPMC) and Methyl Cellulose (MC). These solid dispersions were analyzed for the solubility and in-vitro dissolution profile solid dispersion of drug with polymer has shown enhanced solubility with improved dissolution rate. Further FTIR, X-Ray studies were carried out. Solid dispersion prepared with polymer in 1:5 ratios shows the presence of amorphous form confirmed by the characterization study. The study also shows that dissolution rate of simvastatin can be enhanced to considerable extent by solid dispersion technique with Polymer.

Keywords: Solubility enhancement, Solid dispersion, Low aqueous solubility

Article Info: Received 09 Jan, 2018; Review Completed 27 Feb, 2018; Accepted 01 march, 2018; Available online 15 March, 2018

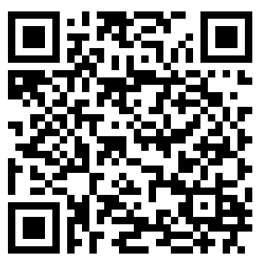

Cite this article as:

Komal, Kaur T, Singh Ajit P, Singh Amar P, Sharma P, Enhancement of solubility and dissolution rate of simvastatin by using solid dispersion technique along with different combination of polymers, Journal of Drug Delivery and Therapeutics. 2018; 8(2):32-40

DOI: http://dx.doi.org/10.22270/jddt.v8i2.1668

*Address for Correspondence

Taranjit Kaur, Department of Pharmaceutics, St. Soldier Institute of Pharmacy, Jalandhar, Punjab, India, Phone: 9815175610

\section{INTRODUCTION}

In recent years, many drug delivery systems like soild dispersion $^{1}$, liposome ${ }^{2,3}$, nanoemulsion etc used in order to model the kinetics release, improve the absorption and increase stability drugs. From this arose the main difficulties with regard to the development and the therapeutic activity of many drugs, which results in large part to the low aqueous solubility of drugs 1 .

Thus, some techniques can be used to increase the solubility of drugs, independent of their chemical structure and dimension Molecular space ${ }^{\mathbf{4}, 5}$. Since solid dispersion increases the solubility of the drugs, it has become one of the most active areas of research in the pharmaceutical field. This technique produces a significant reduction in particle size drug with increased uniformity and surface contact, allowing dissolution and faster absorption ${ }^{6}$.

The production of solid dispersions (SDs) is one of the acknowledged methods and used to enhance the aqueous solubility, thereby increasing the oral bioavailability and dissolution rate of drugs with aqueous low solubility ${ }^{1,7}$.

Because of the toxicity and environmental problems associated with the use of organic solvents, the use the fusion method represents an advantageous means in Preparation of SD when the drug is stable Thermal. However, its use is inappropriate when there 
polymorphism due to transition that may occur during fusion between the polymorphic forms ${ }^{\mathbf{8}, \mathbf{9}}$.

Simvastatin (BCS II drug) is a white crystalline powder form and $(1 S, 3 R, 7 S, 8 S, 8 \mathrm{a} R)-1,2,3,7,8,8 \mathrm{a}-$ hexahydro-3,7-dimethyl-8-[2-[(2R,4R)-tetrahydro-4hydroxy-6-oxo-2H-pyran-2yl]ethyl]-1-naphthalenyl ester. After oral ingestion, SMS, an inactive lactone, is hydrolyzed to the corresponding $\beta$-hydroxyacid form. This is a principal metabolite and an inhibitor of 3hydroxy-3-methylglutaryl-coenzyme-A (HMG Co-A) reductase, the enzyme that catalyses an early and ratelimiting step in the biosynthesis of cholesterol. It is a Hypolipidemic drug having a potent inhibitor of HMGCoA reductase inhibitor and used to treat the Hypercholestremia, Dyslipidemia and coronary heart diseases. 10, 11, 12 Hdroxy Propyl Methyl Cellulose (HPMC) is a 2-hydroxy propyl methyl ether and soluble in ethanol, methanol and propanol. Methyl Cellulose (MC) is a Methyl Ether of Cellulose and soluble in water, glacial acetic acid and both these polymers used as a soluility enhancer and improving the dissolution rate of water insoluble drug.

\section{MATERIAL AND METHODS}

\section{Materials}

The Simvastatin gift sample was received from Dr. Reddys' Pharmaceuticals' Ltd. Hyderabad. The Hydroxy propyl methyl cellulose (HPMC) and Methyl cellulose (MC) polymers were gifted from Signet Chemicals Pvt. Ltd and Loba Chem Pvt. Ltd Mumbai. The other chemicals are ethanol, methanol, magnesium state, talc, lactose; disodium hydrogen orthophosphate and potassium dihydrogen orthophosphate were purchased from Loba Chemicals Mumbai, India.

\section{Methods $^{9}$}

\section{Physiochemical Characterisation of Pure Drug}

The drug sample (Simvastatin) was analysed by different means such as color, odor and texture in order to prove the authenticity of the sample.

\section{Determine the Solubility of Pure Drug by using UV} Spectroscopic Method

\section{A. Determination Absorption Maxima of the $\operatorname{Drug}\left(\lambda_{\text {max }}\right)$}

A UV absorption maxima of the drug was determined by scanning $(10 \mu \mathrm{g} / \mathrm{ml})$ solution of drug in methanol between $200-400 \mathrm{~nm}$.

\section{B. Preparation of Calibration Curve in phosphate buffer (pH 6.8)}

$10 \mathrm{mg}$ of Simvastatin was dissolved in small amount of methanol (used as co solvent) and diluted to $100 \mathrm{ml}$ of phosphate buffer pH6.8. $50 \mathrm{ml}$ of this solution was taken and diluted to $100 \mathrm{ml}$ with phosphate buffer pH6.8 to prepare a stock solution of $250 \mu \mathrm{g} / \mathrm{ml}$ as a stock solution. From this stock solution, aliquots of 2 , $4,6,8,10$ and 12 were transferred to $10 \mathrm{ml}$ volumetric flask and volume was made up to $10 \mathrm{ml}$ with phosphate buffer. The absorbance of these solutions was measured at $239.5 \mathrm{~nm}$ using phosphate buffer as blank.

\section{Preparation of Calibration Curve in Methanol}

$10 \mathrm{mg}$ of Simvastatin was dissolved in $100 \mathrm{ml}$ methanol; $50 \mathrm{ml}$ of this solution was taken and diluted to $100 \mathrm{ml}$ again with methanol to prepare a stock solution of $250 \mu \mathrm{g} / \mathrm{ml}$ as a stock solution. From this stock solution, aliquots of 2, 4, 6, 8, 10 and 12 were transferred to $10 \mathrm{ml}$ volumetric flask and volume was made up to $10 \mathrm{ml}$ with methanol. The absorbance of these solutions was measured at $238 \mathrm{~nm}$ using methanol as blank.

\section{Preparation of solid dispersions of simvastatin Melt Method ${ }^{7}$}

The fusion method is sometimes referred to as the melt method. The polymer HPMC was melted at $60^{\circ} \mathrm{C}$ and then the drug was added, mixed well and cooled in an ice bath to obtain a solid mass. The solidified mass was crushed and passed through a sieve No. 60. The resulting solid dispersion was stored in a desiccator until further evalution.Same procedure carry out with methyl cellulose.

\section{Characterization of solid dispersions ${ }^{9,13,14}$}

The prepared physical mixtures and solid dispersions were evaluated for percentage yield, drug content, solubility studies, Fourier transform infrared (FTIR), Differential scanning calorimetry (DSC), X-ray diffraction (XRD), in vitro drug release and dissolution efficiency.

\section{Percentage of Practical Yield}

The percent yield of Simvastatin solid dispersions was determined by using the following formula:

$[$ PY $(\%)=[$ Practical Mass (Solid dispersion)/ Theoretical Mass (Drug+ Carrier) $\times 100]$ eq 1

\section{Determination of Drug Content}

Solid dispersions equivalent to $10 \mathrm{mg}$ of Simvastatin were weighed accurately and dissolved in $10 \mathrm{ml}$ of methanol. The solution was filtered, diluted suitably and drug content was analyzed at $238 \mathrm{~nm}$ by UV Spectrophotometer.

\section{In vitro Drug Release}

Accurately weighed preparations equivalent to $10 \mathrm{mg}$ of Simvastatin were added to $900 \mathrm{ml}$ of dissolution media (6.8 phosphate buffer) contained in USP dissolution apparatus II and stirred at a speed of 50 $\mathrm{rpm}$ at $37 \pm 0.5^{\circ} \mathrm{C} .5 \mathrm{ml}$ aliquots were withdrawn at 10 , 20, 30, 40, 5060 minute and replaced by $5 \mathrm{ml}$ of fresh dissolution media $\left(37^{\circ} \mathrm{C}\right)$. The collected samples were analyzed after suitable dilution at $239.5 \mathrm{~nm}$ using UVvisible spectrophotometer against the blank. The dissolution of pure Simvastatin was done similarly.

\section{Saturation solubility studies}

Saturation solubility was determined by adding excess amounts of solid dispersions to water and bio relevant media at $37 \pm 0.5^{\circ} \mathrm{C}$, respectively. The solutions were 
equilibrated under continuous agitation for $24 \mathrm{~h}$ and filtered through Whatman filter paper to obtain a clear solution. The absorbance of the samples was measured by UV spectrophotometer (WFZ 800-D2, Beijing Second Telescope Factory) at $238 \mathrm{~nm}$ and the concentrations in $\mu \mathrm{g} / \mathrm{ml}$ were determined. Each sample was determined in triplicate.

\section{Powder X-Ray Diffraction (XRD) Analysis}

The crystallinity of samples was investigated by XRPD using Bruker diffractometer (WI 1140, Japan) and $\mathrm{Cu}-$ $\mathrm{K} \alpha$ radiation. The diffractograms were run at $2.5{ }^{\circ} \mathrm{C}$ min- 1 and chart speed of $2 \% / 2 \mathrm{~cm}$ per $2 \theta$ angle.

\section{Fourier Transform Infrared (FTIR) Spectroscopy}

Simvastatin and solid dispersions were further characterized by FT-IR. Samples prepared in $\mathrm{KBr}$ discs were subjected to FTIR recording on FTIR- 8400S, CE (Shimadzu, Japan) instrument (SEM). Data was collected over a spectral range of 4000 to $400 \mathrm{~cm}^{-1}$.

After the characterisation of the prepared solid dispersions on the basis of dissolution studies and optimise the formulation from the drug release studies and select the highest drug:polymer ratio which shows maximum release in the phosphate buffer pH6.8. and its calculative parameters as shown respectively.

\section{Stability studies}

Accelerated stability studies were performed on prepared solid dispersion in amber coloured screw capped bottles and was checked as per ICH guidelines at $40 \pm 2^{\circ} \mathrm{C}$ and $75 \pm 5 \% \mathrm{RH}$ up to one month. The solid dispersions were kept in stability chamber. Samples were removed at regular intervals as initial, 7 days, 14 days, 21days and 30 days and were analysed for physical characterization, content uniformity and in vitro dissolution studies. The similarity factor (f2) was used as a basis to compare dissolution profiles. The dissolution profiles. The dissolution profiles are considered to be similar when $\mathrm{f} 2$ is between 50 and 100. The dissolution profiles of $\mathrm{C} 1$ formulation before and after stability testing were compared using a similarity factor (f2) which is a calculated from the following formula.

$$
f_{2}=50 \log \left\{\left[1+\frac{1}{n} \sum_{t=1}^{n}\left(R_{t}-T_{t}\right)^{2}\right]^{-0.5} 100\right\}
$$

Where, $n$ is the dissolution time and $R_{j}$ and $T_{j}$ are the reference and test dissolution values at time $t$. (Morre Flamer equation).

A model independent method for comparison of two dissolution profiles is based upon similarity factor $\mathrm{f}_{2}$ and difference factor $\mathrm{f}_{1}$ similarity factor as discussed above, the equation of difference factor discussed below.

$$
\begin{aligned}
& \mathbf{f}_{2}=\sum_{t=1}^{n}\left(\mathbf{R}_{\mathbf{t}}-\mathbf{T}_{\mathbf{t}}\right) / \sum_{t=\mathbf{1}}^{n} \mathbf{R}_{\mathbf{t}} \\
& \text { eq } 3
\end{aligned}
$$

\section{RESULT AND DISCUSSION}

\section{Physical Appearance}

Physical appearance of drug was studied by its various organoleptic properties. The sample of simvastatin was found to be white, non hygroscopic, crystalline solid powder. The melting point of simvastatin was found to be in the range of $135-140^{\circ} \mathrm{C}$ by Capillary method.

\section{Absorption Maxima}

Absorption maxima ( $\lambda$ max) of simvastatin were observed in different solvents.

Table 1: Absorption maxima ( $\lambda \max )$ of the Simvastatin

\begin{tabular}{|c|c|}
\hline Solvent & $(\boldsymbol{\lambda} \mathbf{m a x}) \mathbf{n m}$ \\
\hline Phosphate buffer & $239 \mathrm{~nm}$ \\
\hline Methanol & $238 \mathrm{~nm}$ \\
\hline
\end{tabular}

\section{Solubility}

The solubility studies of Simvastatin were determined in different solvents.

Table 2 Solubility of Simvastatin in different solvents

\begin{tabular}{|c|c|}
\hline Solvent & Solubility \\
\hline Phosphate buffer & $4.036 \pm 0.549$ \\
\hline Methanol & $2.516 \pm 0.166$ \\
\hline
\end{tabular}

Data Expressed as mean \pm S.D $(n=3)$

\section{Standard curves}

The standard curve of simvastatin was found to be linear at $237 \mathrm{~nm}$ in phosphate buffer $(\mathrm{pH} 6.8)$ in the concentration range of $2-12(\mu \mathrm{g} / \mathrm{ml})$, which obeys Lambart Beer Law. The absorbance at different concentrations is shown in tables and graph is represented in figure respectively. 


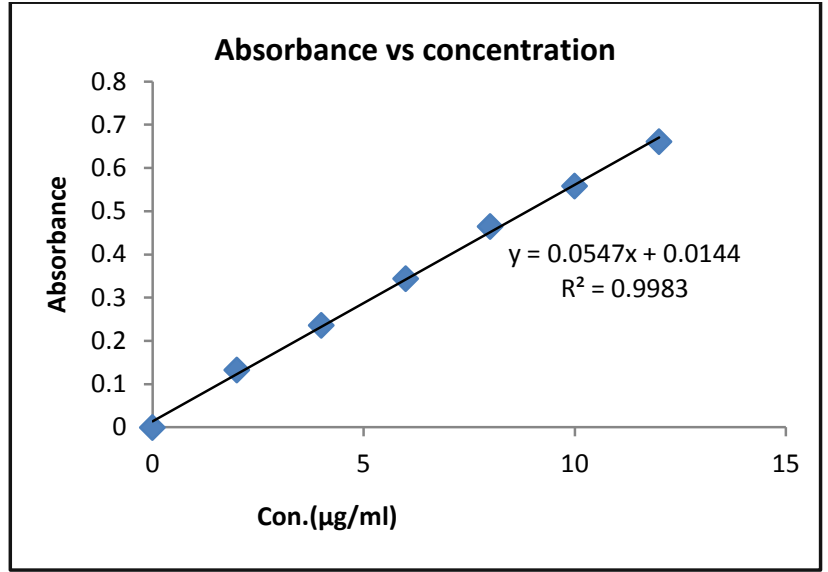

Figure 1: Standard Curve of Simvastatin in Phosphate Buffer (pH6.8)

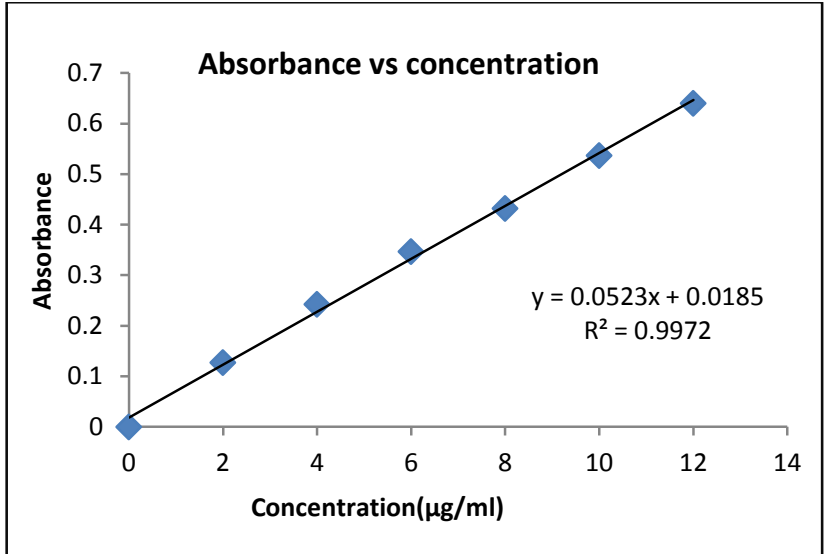

Figure 2: Standard Curve of Simvastatin in Methanol

\section{Percent yield and drug content}

The percent yield and drug content of pure drug and different solid dispersions which are prepared with polymers were determined. The $\%$ yields decreased at the higher concentrations due to the difficulty in sieving at higher polymer and surfactants concentration.

Table 3: Percent yield or drug content of solid dispersions Sim/HPMC

\begin{tabular}{|l|l|l|}
\hline Formulation Code & Percentage yield & Drug content \\
\hline SIH1:1 & $95.52 \pm 0.804$ & $84.42 \pm 0.020$ \\
\hline SIH1:3 & $94.81 \pm 0.635$ & $91.73 \pm 0.006$ \\
\hline SIH1:5 & $90.27 \pm 0.245$ & $95.96 \pm 0.009$ \\
\hline
\end{tabular}

Data Expressed as mean \pm S.D $(n=3)$

Table 4: Percent yield or drug content of solid dispersions Sim/MC

\begin{tabular}{|l|l|l|}
\hline Formulation Code & Percentage yield & Drug content \\
\hline SM1:1 & $90.14 \pm 0.759$ & $77.69 \pm 0.018$ \\
\hline SM1:3 & $89.63 \pm 0.514$ & $87.88 \pm 0.007$ \\
\hline SM1:5 & $89.26 \pm 0.865$ & $84.23 \pm 0.016$ \\
\hline
\end{tabular}

Data Expressed as mean \pm S.D $(n=3)$

Table 5: Percentage yield and drug content of solid dispersion Simvastatin MC: HPMC

\begin{tabular}{|l|l|l|}
\hline Formulation Code & Percentage yield & Drug content \\
\hline SHM1:1 & $92.29 \pm 0.935$ & $85.76 \pm 0.015$ \\
\hline SHM1:3 & $91.99 \pm 0.404$ & $89.61 \pm 0.016$ \\
\hline SHM1:5 & $92.54 \pm 0.402$ & $92.11 \pm 0.007$ \\
\hline
\end{tabular}

Data Expressed as mean \pm S.D $(n=3)$

Solubility studies

Solubility data of pure drug and different solid dispersions as shown in given Table 6 to 8 respectively. Solubility of drug increased with increased in the ratio of polymer. 
Table 6: Solubility of Pure Drug Simvastatin and HPMC

\begin{tabular}{|l|l|}
\hline Formulation Code & Solubility \\
\hline Pure drug & $4.036 \pm 0.549$ \\
\hline SIH 1 & $6.156 \pm 0.645$ \\
\hline SIH2 & $7.043 \pm 0.422$ \\
\hline SIH3 & $8.273 \pm 0.159$ \\
\hline
\end{tabular}

Table 7: Solubility of Pure Drug Simvastatin and MC

\begin{tabular}{|l|l|}
\hline Formulation Code & Solubility \\
\hline Pure drug & $4.036 \pm 0.549$ \\
\hline SM1 & $5.356 \pm 0.285$ \\
\hline SM2 & $6.066 \pm 0.351$ \\
\hline SM3 & $7.676 \pm 0.442$ \\
\hline
\end{tabular}

Data Expressed as mean \pm S.D $(n=3)$

Table 8: Solubility of Pure Drug Simvastatin and HPMC: MC

\begin{tabular}{|l|l|}
\hline Formulation Code & Solubility \\
\hline Pure drug & $4.036 \pm 0.549$ \\
\hline SHM1 & $9.516 \pm 0.232$ \\
\hline SHM2 & $11.186 \pm 0.178$ \\
\hline SHM3 & $12.516 \pm 0.232$ \\
\hline
\end{tabular}

Data Expressed as mean \pm S.D $(n=3)$

\section{In Vitro Dissolution studies}

The In vitro release of pure drug and different solid dispersions were determined and plotted the graph between $\%$ drug released vs time.

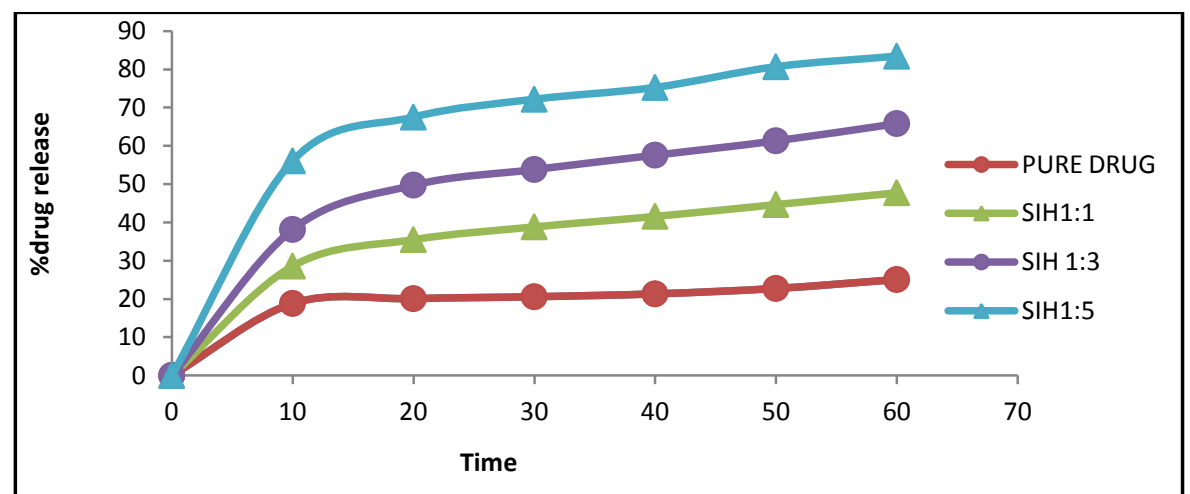

Figure 3: In vitro dissolution profile of \%drug released vs time pure drug and Solid dispersions (Sim/HPMC) 


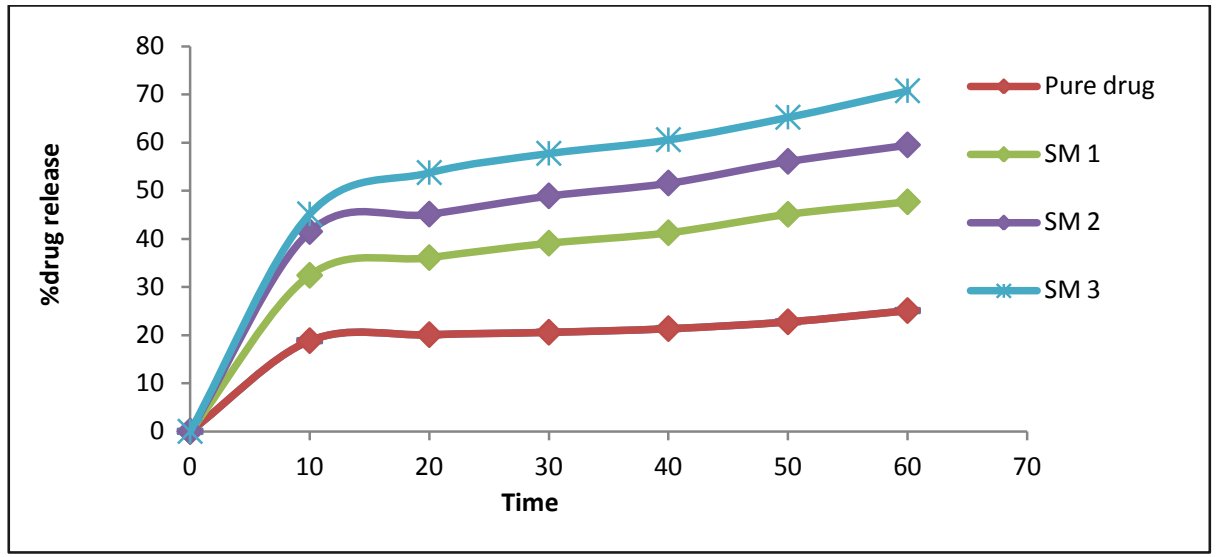

Figure 4: In vitro dissolution profile of \%drug released vs time pure drug and Solid $\operatorname{dispersions}(\mathrm{Sim} / \mathrm{MC})$

\section{X-ray diffraction studies}

The X-ray diffraction studies of pure simvastatin and optimized solid dispersions of both polymers HPMC and Methyl Cellulose. The characteristics diffraction peaks of simvastatin present peaks at (20) 9.63o, 11.24o, $15.90 \mathrm{o}, 16.889 \mathrm{o}, 17.56 \mathrm{o}, 18.04 \mathrm{o}, 19.74 \mathrm{o}, 22.84 \mathrm{o}$,
$28.68 \mathrm{o}, 33.51 \mathrm{o}, 35.17 \mathrm{o}$, and $38.73 \mathrm{o}$ indicate the $\mathrm{pr}$ crystalline nature of the drug. Peaks of optimized solid dispersion shows the reduction in peak height area which indicates the reduction in the crystallinity nature of the simvastatin as some of the drug converted into the amorphous form in the solid dispersions.

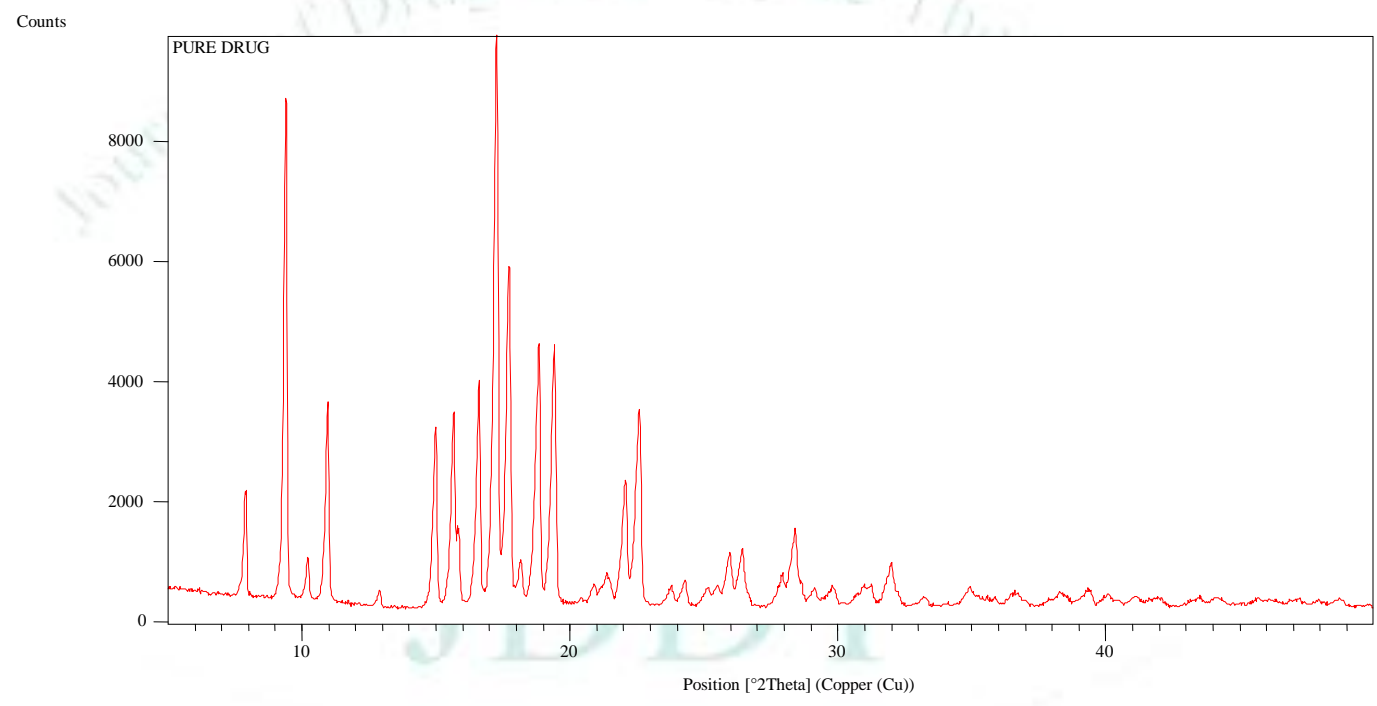

Figure 5: X-ray diffraction of Simvastatin

Counts

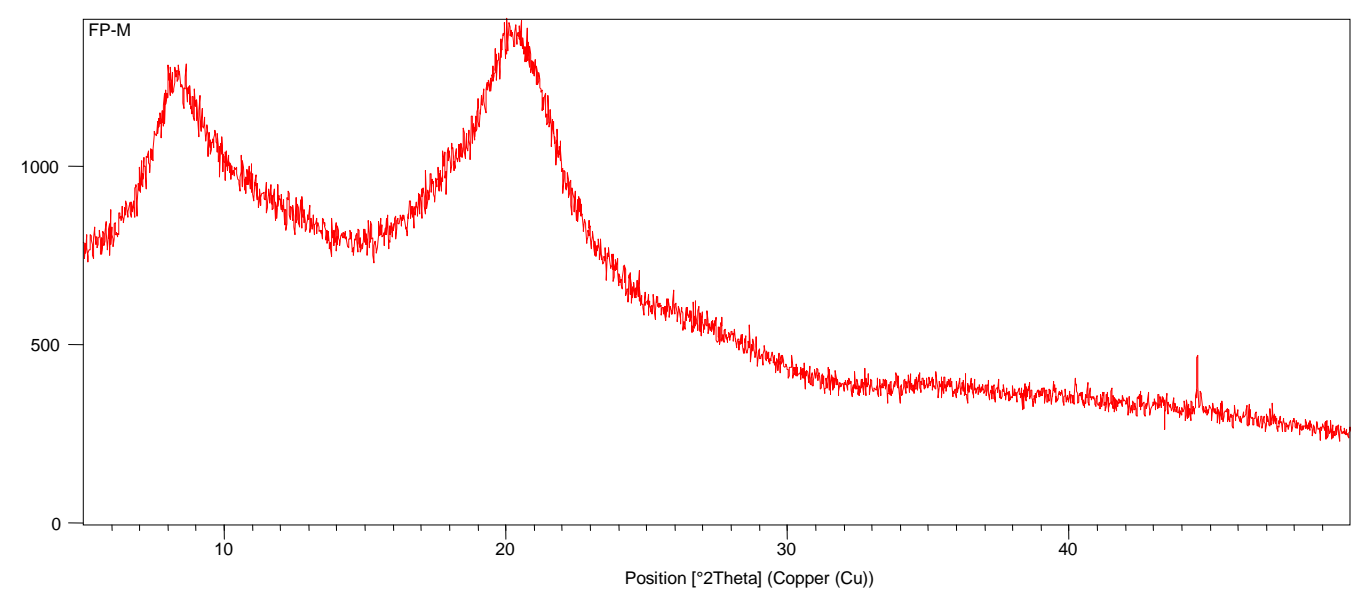

Figure 6: X-ray diffraction of Simvastatin with HPMC/MC 
The spectrum of solid dispersions exhibited significant decrease in intensity of $\mathrm{O}-\mathrm{H}$ stretching vibrations which may be due to intermolecular hydrogen bonding. The spectra peaks of drug were almost unchanged in the optimized solid dispersions which indicate that the overall symmetry of molecule was not affected

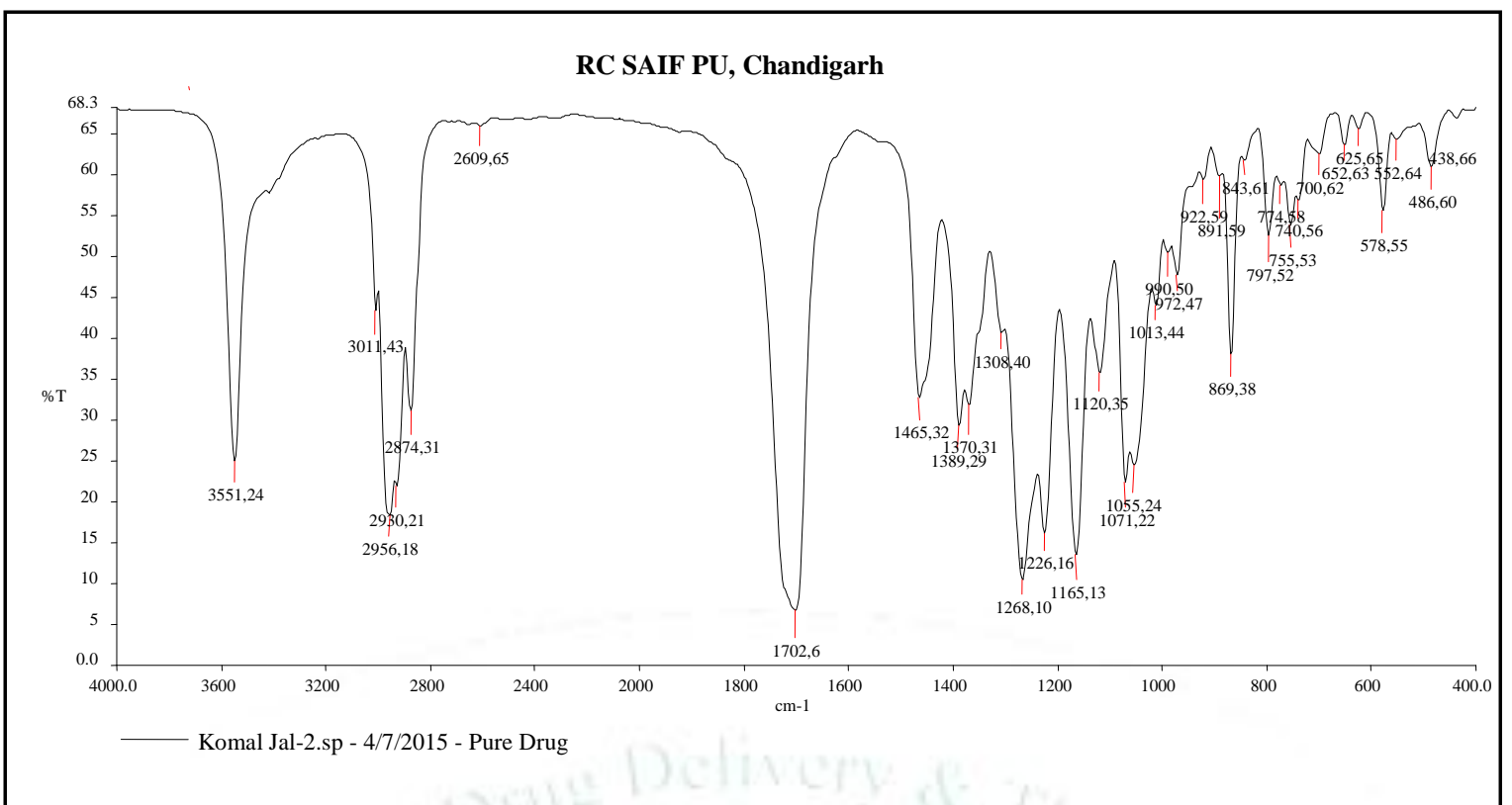

Figure 7: IR Spectra of Simvastatin

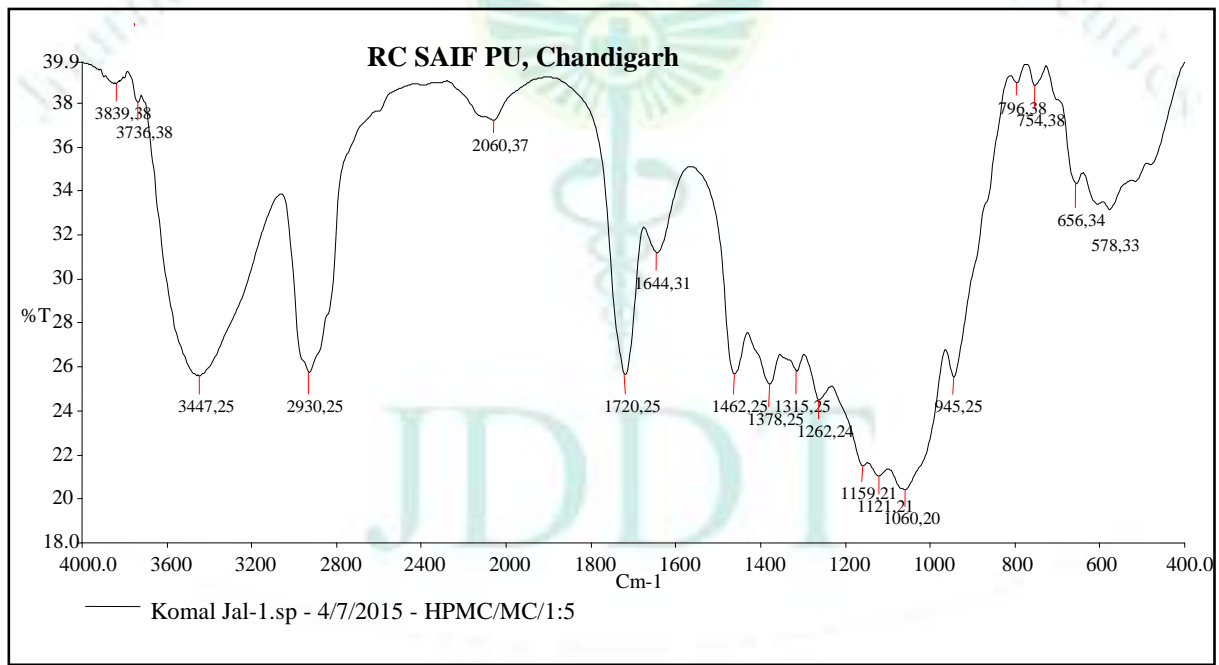

Figure 8: IR Spectra of optimized solid dispersion with (HPMC/MC)

\section{Optimized formulation}

On the basis of dissolution data optimized formulation is detected and formula was prepared which was shown below the table.

Table 9: Dissolution efficiency and yield of optimized formulations

\begin{tabular}{|l|l|l|}
\hline Optimized formulation & $\mathbf{\% D E}_{\mathbf{6 0}}$ & \% Yield \\
\hline $100: 500$ & 65.44 & 90.27 \\
\hline $100: 500$ & 53.41 & 89.26 \\
\hline $100: 250: 250$ & 60.90 & 92.54 \\
\hline
\end{tabular}

Table 10: Evaluation parameters of optimized solid dispersion (HPMC) after stability 


\begin{tabular}{|l|l|l|l|l|l|}
\hline $\begin{array}{l}\text { Time period (in } \\
\text { days) }\end{array}$ & $\mathbf{0}$ & $\mathbf{7 4}$ & $\mathbf{2 1}$ & $\mathbf{3 0}$ \\
\hline Color appearance & $\begin{array}{l}\text { No change in } \\
\text { color }\end{array}$ & $\begin{array}{l}\text { No change in } \\
\text { color }\end{array}$ & $\begin{array}{l}\text { No change in } \\
\text { color }\end{array}$ & $\begin{array}{l}\text { No change in } \\
\text { color }\end{array}$ & $\begin{array}{l}\text { No change in } \\
\text { color }\end{array}$ \\
\hline Drug release & - & - & - & 95.47 \\
\hline
\end{tabular}

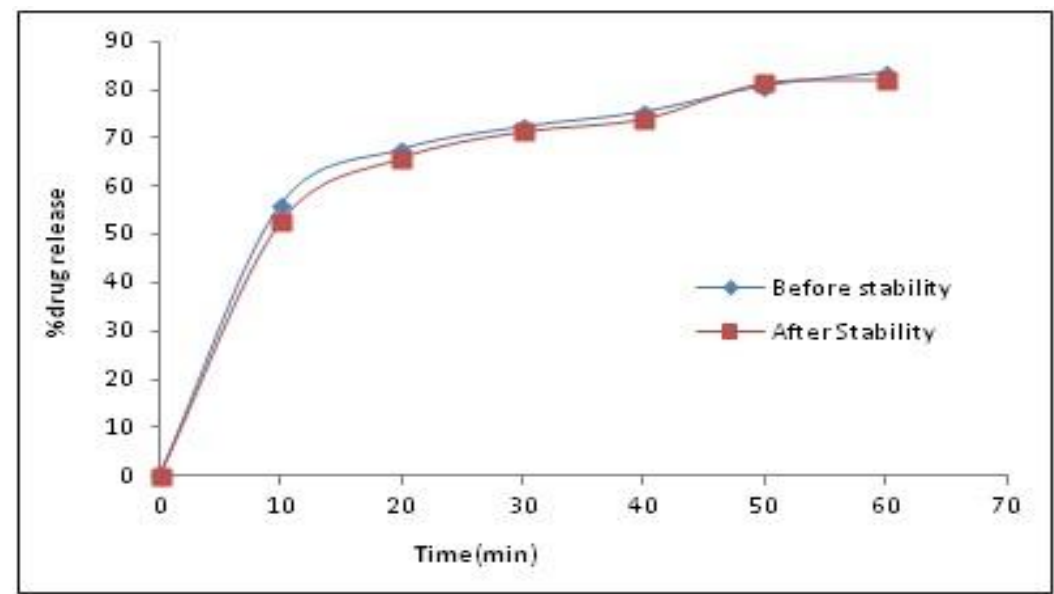

Figure 9: Drug Release Data of Before and After Storage (Sim/HPMC)

Table 11: Evaluation parameters of optimized solid dispersion (MC) after stability

\begin{tabular}{|l|l|l|l|l|l|}
\hline Time period (in days) & $\mathbf{0}$ & $\mathbf{7}$ & $\mathbf{1 4}$ & $\mathbf{2 1}$ & $\mathbf{3 0}$ \\
\hline Color appearance & $\begin{array}{l}\text { No change in } \\
\text { color }\end{array}$ & $\begin{array}{l}\text { No change in } \\
\text { color }\end{array}$ & $\begin{array}{l}\text { No change in } \\
\text { color }\end{array}$ & $\begin{array}{l}\text { No change in } \\
\text { color }\end{array}$ & $\begin{array}{l}\text { No change in } \\
\text { color }\end{array}$ \\
\hline Drug release & - & - & - & - & 91.17 \\
\hline
\end{tabular}

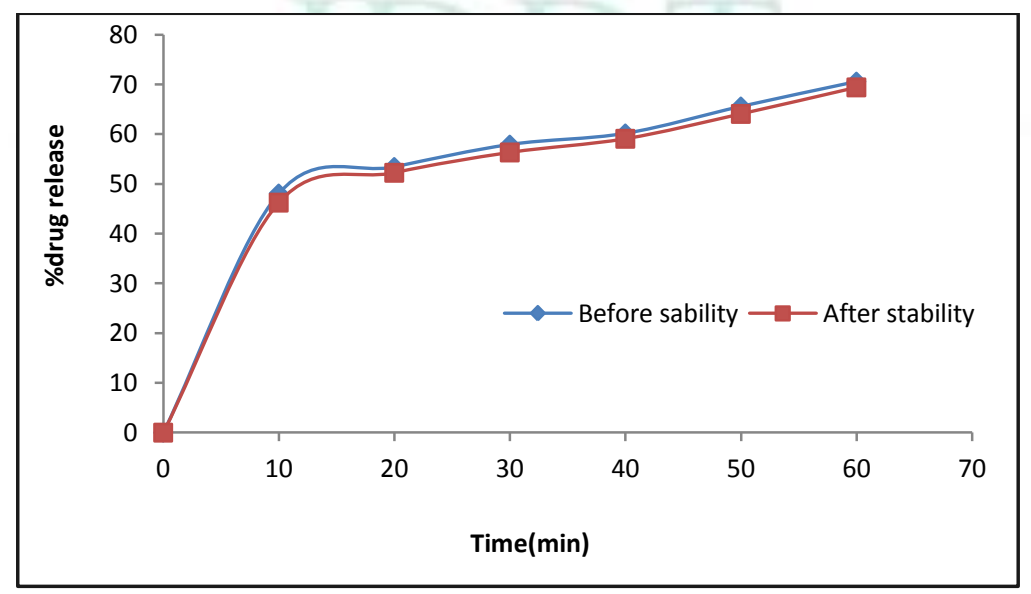

Figure 10: Drug Release Data of Before and After Storage (Sim/MC)

Table 12: Evaluation parameters of optimized solid dispersion (HPMC: MC) after stability

\begin{tabular}{|l|l|l|l|l|l|}
\hline Time period (in days) & $\mathbf{0}$ & $\mathbf{7}$ & $\mathbf{1 4}$ & $\mathbf{2 1}$ & $\mathbf{3 0}$ \\
\hline Color appearance & $\begin{array}{l}\text { No change in } \\
\text { color }\end{array}$ & $\begin{array}{l}\text { No change in } \\
\text { color }\end{array}$ & $\begin{array}{l}\text { No change in } \\
\text { color }\end{array}$ & $\begin{array}{l}\text { No change in No change in } \\
\text { color } \\
\text { color }\end{array}$ & - \\
\hline Drug release & - & - & - & 93.23 \\
\hline
\end{tabular}




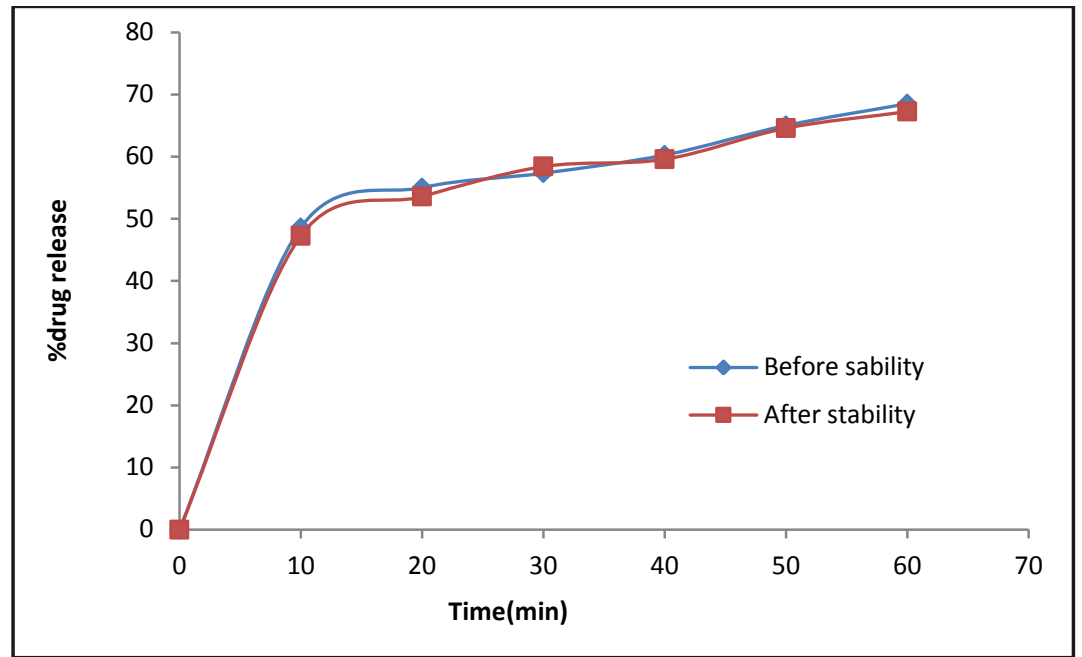

Figure 11: Drug Release Data of Before and After Storage (Sim/MC: HPMC)

From all above the dissolution data, it shows that there will no change from the above dissolution data and graph, that there is no change to be observed in prepared optimized solid dispersion. The value to be calculated from the equation and drug release value is 93.23 that is become met similar with the standard so that the optimized solid dispersion was stable after the stability studies.

\section{REFERENCES}

1. Bhirud Y, Phalak H, Advances in solid dispersion technology and its applications in the development of solid dosage forms. Journal of Drug Delivery and Therapeutics, 2016; 6(6):40-47. doi:10.22270/jddt.v6i6.1316

2. Dwivedi C, Sahu R, Tiwari S, Satapathy T, Roy A, Role of liposome in novel drug delivery system. Journal of Drug Delivery and Therapeutics, 2014; 4(2):116-129.

doi:10.22270/jddt.v4i2.768

3. Asadujjaman M, Mishuk A, Novel approaches in lipid based drug delivery systems. Journal of Drug Delivery and Therapeutics, 2013; 3(4):124-130. doi:10.22270/jddt.v3i4.578

4. Loftsson T, Hreinsdóttir D, Másson M, Evaluation of cyclodextrin solubilization of drugs, International journal of pharmaceutics, 2005, 302(1), 18-28.

5. Singh J, Walia M, Harikumar S, Solubility enhancement by solid dispersion method: a review, Journal of Drug Delivery and Therapeutics, 2013; 3(5):148-55.

6. Bikiaris D, Papageorgiou GZ, Stergiou A, et al., Physicochemical studies on solid dispersions of poorly water-soluble drugs: evaluation of capabilities and limitations of thermal analysis techniques, Thermochimica acta, 2005, 439(1), 58-67.

7. Khan A, Singh L, Various techniques of bioavailability enhancement: a review. Journal of Drug Delivery and Therapeutics, 2016; 6(3):34-41. doi:10.22270/jddt.v6i3.1228

8. Mehta S, Joseph NM, Feleke F, Palani S, Improving solubility of BCS class II drugs using solid dispersion: a review, Journal of Drug Delivery and Therapeutics, 2014, 4(3), 7-13.

9. Shende M, Fiske P, Fabrication and optimization of novel glipizide sustained release matrices for solubility and dissolution enhancement by solid dispersion through hydrophillic carriers. Journal of Drug Delivery and Therapeutics, 2017; 7(6):38-48. doi:10.22270/jddt.v7i6.1538

10. Armstrong NA. Pharmaceutical Experimental Design and Interpretation, 2n ed., Taylor \& Francis Group; 2006.

11. Ambike Anshuman .A, Mahadik .R.k., Paradkar 2005 SprayDried Amorphous Solid Dispersions of Simvastatin, a Low Tg In Vitro and invivo Evaluations Pharmaceutical Research P No.990-998.

12. Seoung Wook Jun, Min-Soo Kim, Jeong-Soo Kim, Hee Jun Park, Sibeum Lee, Jong Soo Woo Sung-Joo Hwang Preparation and characterization simvastatin/hydroxypropylb-cyclodextrin inclusion complex using supercritical antisolvent (SAS) process European Journal of Pharmaceutics and Biopharmaceutics, 66 (2007) 413-421.

13. Verma S, Patel U, Patel R, Formulation and evaluation of ivermectin solid dispersion. Journal of Drug Delivery and Therapeutics, 2017; 7(7):15-17.

14. Nagasamy VD, Arun R, Saraswathi S, Padma Priya MS, Khan NI, Kathirulla N, Sruthi S, Dissolution enhancement of diacerein using water soluble carrier by solid dispersion technology, Journal of Drug Delivery and Therapeutics. 2017; 7(5):33-41 DOI: http://dx.doi.org/10.22270/jddt.v7i5.1503 